\title{
Rancang Bangun Sensor Node untuk Pemantauan Parameter Kualitas Udara
}

\author{
Heri Subagiyo ${ }^{1}$, Retno Tri Wahyuni ${ }^{2}$, Memen Akbar ${ }^{3}$, Fella Ulfa $^{4}$ \\ 1,2,4 Program Studi Teknik Elektronika, Jurusan Teknologi Industri, Politeknik Caltex Riau \\ Jl. Umbansari, Rumbai, Pekanbaru, 28265 \\ Email: heri@pcr.ac.id, retnotri@pcr.ac.id, fellaulfa@alumni.pcr.ac.id \\ ${ }^{3}$ Program Studi Teknik Komputer, Jurusan Teknologi Informasi, Politeknik Caltex Riau \\ Jl. Umbansari, Rumbai, Pekanbaru, 28265 \\ Email: memen@pcr.ac.id
}

\begin{abstract}
ABSTRAK
Sensor Node untuk pemantauan parameter kualitas udara merupakan perangkat pengukuran parameter kondisi kualitas udara pada suatu titik lokasi tertentu. Parameter yang diukur berdasarkan ISPU (Indeks Standar Pencemaran Udara) meliputi gas karbon monoksida (CO), nitrogen dioksida (NO2), sulfur dioksida (SO2), ozon (O3), dan partikel debu (PM10). Komponen yang digunakan pada sensor node yaitu mikrokontroler Arduino Uno, sensor MQ-7, sensor MQ-131, sensor MQ-135, sensor MQ-136, sensor GP2Y1010AU0F dan WiFi module. Sistem ini dikendalikan oleh mikrokontroler yang berfungsi untuk mengelola data hasil pengukuran sensor. Data mentah yang dibaca dari sensor dikonversi menjadi konsentrasi gas/partikulat debu dalam satuan ppm. Persamaan konversi diperoleh berdasarkan grafik hubungan keluaran sensor dan ppm yang tercantum pada datasheet sensor. Data tersebut selanjutnya dikirim ke server melalui WiFi module. Pengujian keseluruhan dilakukan dengan melakukan pengukuran parameter kualitas udara pada dua titik secara bersamaan di Kota Pekanbaru. Hasil pengujian menunjukkan bahwa keseluruhan sistem dapat berjalan baik dan data berhasil dikirim ke server. Hasil pengukuran sudah berada pada daerah pengukuran masing-masing parameter kualitas udara. Hasil ini menunjukkan bahwa sistem dapat digunakan sebagai langkah awal pengembangan sistem monitoring kualitas udara.
\end{abstract}

Kata Kunci: Sensor Node, Mikrokontroler, Monitoring, Kualitas Udara

\begin{abstract}
Sensor Node for air quality monitoring is a device for measuring parameters of air quality conditions at a certain location. Parameters measured based on the Air Pollution Standard Index (ISPU) include carbon monoxide $(\mathrm{CO})$, nitrogen dioxide (NO2), sulfur dioxide (SO2), ozone (O3), and dust particles (PM10). The components used on the sensor node are Arduino Uno microcontroller, MQ-7 sensor, MQ-131 sensor, MQ-135 sensor, MQ-136 sensor, GP2Y1010AUOF sensor and WiFi module. This system is controlled by microcontroller which functions to manage sensor measurement data. The raw data read from the sensor is converted to the concentration of gas / particulate dust in units of ppm. The conversion equation is obtained based on the graph of the sensor output relationship and ppm which is listed on the sensor datasheet. The data is then sent to the server via the WiFi module. The overall test was carried out by measuring the air quality at two points simultaneously in Pekanbaru City. The test results show that the whole system is running well and data has been successfully sent to the server. The measurement results are already in the measurement area of each air quality parameter. These results indicate that the system can be used as an initial step in developing an air quality monitoring system.
\end{abstract}

Keywords: Sensor Node, Microcontroller, Monitoring, Air Quality

\section{Pendahuluan}

Udara merupakan salah satu komponen lingkungan yang penting dan menjadi kebutuhan mendasar bagi manusia dan makhluk hidup lain. Tanpa makanan dan air, manusia mampu bertahan hidup sekitar 5 hari. Namun tanpa udara, manusia hanya dapat bertahan hidup selama sekitar 5 menit (Prabowo \& Muslim, 2018). Udara lingkungan yang bersih dapat meningkatkan kesehatan, vitalitas, dan daya tahan tubuh. Selain itu juga dapat memperpanjang harapan hidup seseorang. Sebaliknya, udara tercemar dapat menyebabkan gangguan kesehatan hingga kematian (Arty, 2005).

Dalam World Air Quality Report 2019 dilaporkan tentang peringkat kota-kota paling tercemar di dunia sepanjang tahun 2019. Dalam laporan tersebut, IQAir menyoroti peningkatan polusi udara sepanjang 2019. Polusi tersebut ada yang diakibatkan oleh perubahan iklim, seperti badai pasir dan kebakaran hutan. Namun ada pula polusi 
akibat semakin cepatnya urbanisasi kota, seperti yang terjadi di wilayah Asia Tenggara (IQAir, 2020).

Perubahan kualitas udara secara dramatis juga terlihat di Indonesia selama dua puluh tahun terakhir. Indonesia beralih dari salah satu negara paling bersih menjadi salah satu dari dua puluh negara paling berpolusi di dunia. Konsentrasi polusi partikulat udara di Indonesia meningkat 171 persen dari tahun 1998 hingga 2016 (Greenstone \& Fan, 2019).

Kualitas udara di Pekanbaru, ibu kota provinsi Riau, selama beberapa tahun terakhir dalam rentang waktu tertentu berada di level status berbahaya dan tidak sehat. Selain polusi akibat aktivitas manusia, juga terutama karena diselimuti kabut asap akibat kebakaran hutan dan lahan (karhutla). Polusi udara karena kabut asap ini sudah menjadi peristiwa tahunan yang terus berulang. Demikian diberitakan oleh Kompas.com pada 13 September 2019 (Aida, 2019). Bahkan situs berita Liputan6.com dalam laporannya tanggal 20 September 2019 tertulis artikel "Lelah, Sudah 22 Tahun Karhutla dan Kabut Asap Menghantui Riau". Dampat kabut asap ini adalah perekonomian lumpuh, bandara ditutup, sekolah diliburkan, dan ribuan warga terjangkit Infeksi Saluran Pernapasan Akut atau ISPA (Syukur, 2019).

Penelitian tentang monitoring kualitas udara terutama untuk daerah perkotaan telah dilakukan oleh beberapa peneliti, diataranya (Suwedi, Rifa'i, \& Sujana, 2018) dan (Gupta, Bhardwaj, Agrawal, Tikkiwal, \& Kumar, 2019). Suatu sistem monitoring kualitas udara perkotaan yang meliputi logger system, data management system, dan GUI system dikembangkan oleh (Suwedi, Rifa'i, \& Sujana, 2018). Data dikirim melalui jalur komunikasi GSM/GPRS. Parameter udara yang diukur adalah $\mathrm{CO}, \mathrm{O}_{2}$ dan $\mathrm{H}_{2} \mathrm{~S}$. Tentu saja parameter ini masih belum mencakup standar parameter udara yang ditetapkan dalam indeks standar pencemar udara (ISPU).

Sementara itu, (Gupta, Bhardwaj, Agrawal, Tikkiwal, \& Kumar, 2019) mengembangkan sistem monitoring polusi udara untuk smart city berbasis IoT. Parameter udara yang diukur adalah suhu, kelembaban, CO, LPG, asap dan partikulat PM2,5 dan PM10. Tentu saja karena berbasis IoT, pengiriman data dilakukan melalui jaringan internet (wifi). Untuk suatu kota yang sudah memiliki jaringan internet sebagai smart city, tentu saja tidak menjadi masalah. Namun demikian, untuk kota yang belum memiliki infrastruktur jaringan internet memadai perlu solusi lain. Termasuk jika sistem monitoring akan dikembangkan untuk daerah di luar perkotaan.

Penelitian tentang monitoring kualitas udara juga telah dilakukan beberapa peneliti di kota Pekanbaru, diantaranya adalah (Timisela, 2011) dan (Savitri, 2016). Dalam (Timisela, 2011), kandungan gas yang diukur adalah karbondioksida $\left(\mathrm{CO}_{2}\right)$, karbonmonoksida $(\mathrm{CO})$, dan metana $\left(\mathrm{CH}_{4}\right)$. Data dikirim melalui media wireless (wifi) kemudian ditampilkan pada Personal Computer (PC). Jarak antara sensor dan PC maksimal 300 meter. Jarak ini tentu saja masih belum memadai untuk menjangkau area satu kota.

Sedangkan (Savitri, 2016) menggunakan jaringan GSM untuk pengiriman data setiap jam sekali secara berkala. Dari sisi jarak sudah sangat cukup karena menggunakan jaringan GSM. Namun demikian, parameter kualitas udara yang diukur hanya satu, yaitu partikulat PM2.5. Selain itu jumlah sensor node juga hanya satu buah.

Dalam beberapa penelitian tersebut belum semua parameter kualitas udara yang diukur tercakup dalam satu sensor node. Jumlah dan jarak sensor node yang diujicoba juga hanya satu buah dan masih dalam jarak dekat. Aspek-aspek inilah yang perlu diatasi melalui penelitian yang hasilnya disajikan dalam makalah ini.

Makalah ini menyajikan hasil penelitian tentang rancang bangun sensor node untuk pemantauan parameter kualitas udara. Dalam satu sensor node diintegrasikan seluruh komponen parameter kualitas udara. Sehingga sensor node ini merupakan sensor node untuk pengukuran parameter kualitas udara yang lengkap. Jumlah sensor node yang diujicoba adalah dua buah dan diletakkan di dua lokasi berbeda di kota Pekanbaru. Hal ini untuk menguji pengukuran lebih dari satu titik.

Pembahasan dalam makalah ini difokuskan pada integrasi sensor seluruh parameter kualitas udara dalam satu sensor node dan pengiriman data dari dua sensor node ke server database. Aspek akurasi dan kalibrasi belum dibahas dalam makalah ini dan menjadi bagian untuk pengembangan lebih lanjut.

Pada bagian awal makalah ini akan dibahas secara singkat tentang kualitas udara dan indeks standar pencemar udara, untuk mengetahui parameter udara apa saja yang diukur dalam pemantauan kualitas udara. Selanjutnya disajikan rancang bangun sensor node. Kemudian diikuti pembahasan tentang pengujian dan diskusi hasil pengujian. Pada bagian akhir disampaikan kesimpulan dan saran.

\section{Kualitas Udara}

Kualitas udara adalah keadaan udara dengan kandungan gas atau partikulat tertentu yang berkaitan dengan kesehatan manusia. Kualitas udara dinilai dari konsentrasi parameter pencemar udara yang terukur lebih tinggi atau lebih rendah dari nilai Baku Mutu Udara Ambien. Baku mutu udara ambien adalah ukuran batas atau kadar unsur pencemaran udara yang terdapat dalam udara ambien.

Baku mutu udara ambien nasional Indonesia ditetapkan sebagai batas maksimum mutu udara ambien untuk mencegah terjadinya pencemaran udara dan berlaku di wilayah Indonesia. Parameter udara yang termasuk dalam penentuan baku mutu 
udara ambien yaitu karbon monoksida (CO), nitrogen dioksida $\left(\mathrm{NO}_{2}\right)$, sulfur dioksida $\left(\mathrm{SO}_{2}\right)$, oksidan dalam bentuk ozon $\left(\mathrm{O}_{3}\right)$, dan partikulat berukuran $10 \mu \mathrm{m}$ (PM10).

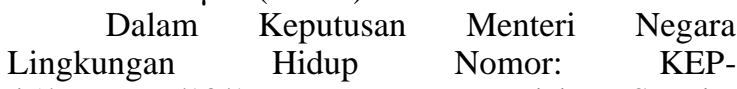
45/MENLH/10/1997 Tentang Indeks Standar Pencemar Udara (ISPU) dijelaskan bahwa Indeks Standar Pencemar Udara (ISPU) adalah angka yang tidak mempunyai satuan yang menggambarkan kondisi kualitas udara ambien di lokasi dan waktu tertentu. Nilai angka ini didasarkan kepada dampaknya terhadap kesehatan manusia, nilai estetika dan makhluk hidup lainnya. Indeks yang menunjukkan level pencemaran ini juga didasarkan pada lima parameter yang sama dengan penentuan baku mutu udara ambien diatas.

Oleh karena itu, dalam penelitian ini keseluruhan sensor yang diperlukan untuk mengukur kelima parameter kualitas udara tersebut disatukan dalam satu sensor node.

\section{Perancangan Sensor Node}

\section{Blok Diagram dan Skematik Rangkaian}

Sensor node merupakan sistem mikrokontroller bersama dengan sensor-sensor yang dibutuhkan untuk pengukuran parameter kualitas udara, yaitu MQ-7, MQ-136, MQ-135, MQ-131, dan GP2Y1010AU0F masing-masing untuk mengukur paramater gas $\mathrm{CO}, \mathrm{NO}_{2}, \mathrm{SO}_{2}, \mathrm{O}_{3}$, dan partikulat PM10. Sensor node juga dilengkapi dengan LCD, RTC (Real Time Clock), GPS, dan Wifi. Diagram blok sensor node dapat dilihat pada Gambar 1.

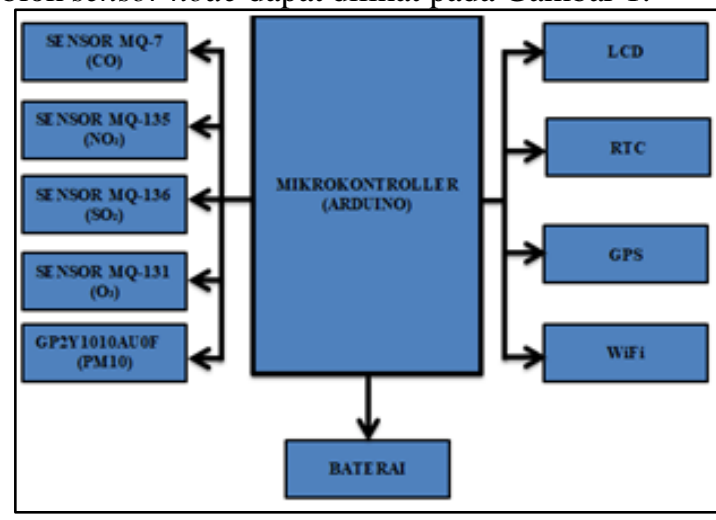

Gambar 1. Diagram blok sensor node

Mikrokontroler (Arduino) berfungsi sebagai penerima dan pengolah data output dari sensor. Selain itu mikrokontroler juga berfungsi mengatur dan menampilkan hasil pengukuran ke LCD. LCD $16 \times 2$, sebagai indikator tampilan data yang diterima dan juga sebagai penampil waktu, tanggal dan data kadar konsentrasi $\mathrm{CO}, \mathrm{NO}_{2}, \mathrm{SO}_{2}, \mathrm{O}_{3}$, dan PM10.

Real Time Clock (RTC) berfungsi mencatat tanggal dan waktu secara secara real time. Modul ini diperlukan kita dapat mencatat tanggal dan waktu pengukuran. Modul GPS berfungsi mendeteksi lokasi sensor node dengan menerima dan memproses sinyal dari satelit navigasi. Selain itu juga dapat digunakan untuk keperluan pelacakan lokasi. WiFi berfungsi sebagai perangkat tambahan mikrokontroler Arduino agar dapat terhubung langsung dengan jaringan wifi. Modul ini diperlukan untuk membuat koneksi ke server melalui jaringan internet dan protokol komunikasi TCP/IP.

Skematik rangkaian sensor node ini diperlihatkan pada Gambar 2. Kaki VCC dan GND setiap modul saling terhubung ke sumber daya. Kaki masukan analog A0, A1, A2, A3, dan A4 mikrokontroller Arduino dihubungkan dengan keluaran masing-masing sensor. Kaki SCL dan SDA mikrokontroller terhubung dengan kaki SCL dan SDA pada modul LCD dan RTC. Sedangkan kaki RX dan TX modul GPS terhubung ke kaki 3 dan 4 dari mikrokontroller Arduino.

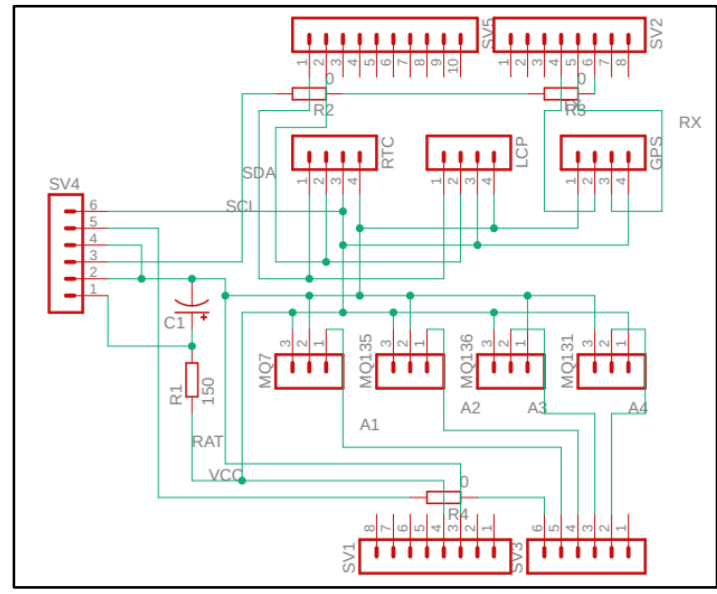

Gambar 2. Skematik rangkaian

\section{Diagram Alir Program}

Tujuan pemrograman pada mikrokontroller sensor node ini adalah untuk mengetahui berapa nilai kadar gas di udara setelah pengukuran melalui sensor dilakukan dan data hasil pengukuran telah dibaca oleh mikrokontroller. Kemudian nilai kadar gas ditampilkan pada LCD dan dikirim ke server database. Program mikrokontroller yang dibuat pada penelitian ini sesuai flowchart yang ditunjukkan pada Gambar 3.

Proses kerja dimulai dengan inisialisasi sensor MQ7, MQ135, MQ136, MQ131, PM10, RTC dan LCD. Setelah itu, mikrokontroller membaca nilai keluaran analog pada sensor MQ7, MQ135, MQ136, MQ131, dan PM10. Nilai analog masingmasing sensor yang sudah terbaca ini selanjutnya akan dikonversi menjadi nilai konsentrasi gas $\mathrm{CO}$, $\mathrm{NO} 2, \mathrm{SO}_{2}$, dan $\mathrm{O}_{3}$ dalam satuan ppm, serta konsentrasi partikulat PM10 dalam satuan $\mu \mathrm{g} / \mathrm{m}^{3}$.

Selanjutnya dilakukan pemeriksaan koneksi jaringan WiFi. Apabila koneksi WiFi baik, data akan terkirim ke server database dan apabila data tidak berhasil terkirim ke server database maka periksa koneksi WiFi kembali sampai data berhasil terkirim. Pada program sensor node ini terdapat proses tunda 
(delay) 30 menit sebagai rentang waktu pengukuran dan pengiriman data.

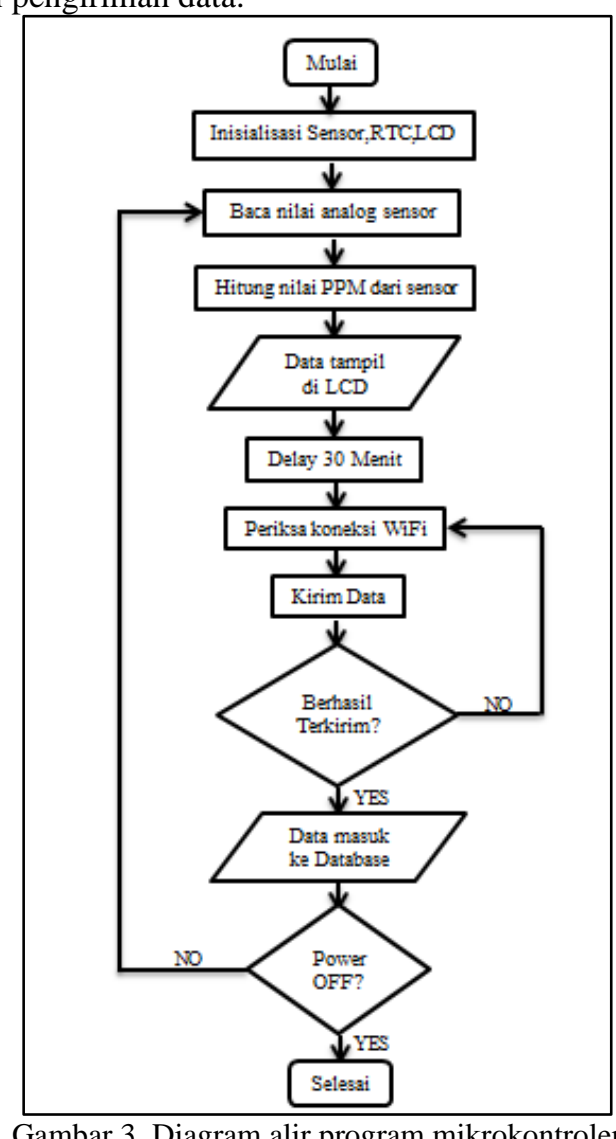

Gambar 3. Diagram alir program mikrokontroler

\section{Persamaan Konversi Keluaran Sensor Menjadi Konsentrasi Gas}

\section{Sensor $M Q 7$}

Kurva karakteristik sensor di perlihatkan pada Gambar 4. Kurva ini diperoleh dari datasheet sensor MQ7. Untuk mendapatkan persamaan sensor, langkah pertama adalah mencari persamaan garis menggunakan Ms. Excel dengan memanfaatkan fitur scatter, scatter with smooth lines and markers. Kemudian klik kiri pada garis dan pilih add trenline, maka akan muncul tampilan trendline options dan pilih Power dan Display Equation on Chart. Selanjutnya perintah Display Equation on Chart akan menampilkan persamaan garis y (ppm) sebagai fungsi dari $\mathrm{x}\left(\mathrm{R}_{\mathrm{s}} / \mathrm{R}_{\mathrm{o}}\right)$.

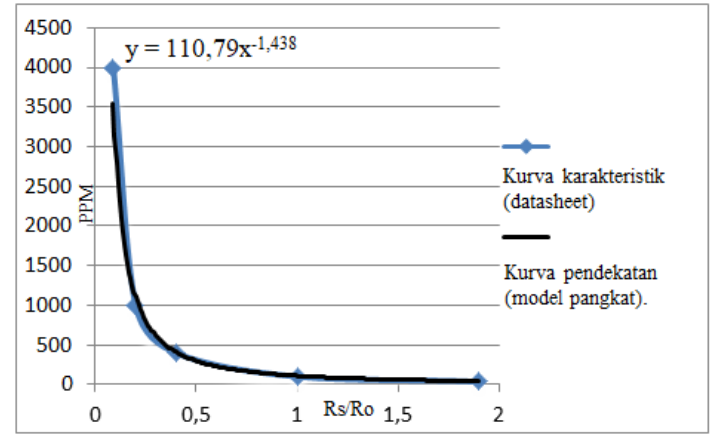

Gambar 4. Kurva karakteristik sensor MQ7

Persamaan kurva pendekatan yang diperoleh tersebut dijadikan sebagai persamaan konversi dari nilai Rs/Ro menjadi ppm, yaitu

$P P M_{C O}=110,79 \times\left(R_{S} / R_{o}\right)^{-1,438}$

dimana $P P M_{C O}$ adalah konsentrasi gas CO dalam satuan $\mathrm{ppm}, R_{s}$ adalah resistansi sensor MQ7 pada saat pengukuran dengan kondisi udara yang berbedabeda, dan $R_{o}$ adalah resistansi sensor MQ7 pada saat kondisi udara bersih $(830 \Omega)$.

Resistansi sensor saat pengukuran $\left(R_{S}\right)$ diperoleh dari perhitungan,

$R_{S}=\left(\left(V_{c} / V_{R L}\right)-1\right) R_{L}$

dimana $V_{c}$ adalah tegangan rangkaian sensor (5 V), $V_{R L}$ adalah tegangan analog keluaran rangkaian modul sensor, dan $R_{L}$ adalah resistansi keluaran rangkaian modul sensor $(1000 \Omega)$.

Pembacaan tegangan keluaran sensor dilakukan melalui ADC internal mikrokonroller Arduino. Resolusi ADC ini adalah 10bit dengan tegangan referensi $5 \mathrm{~V}$. Sehingga untuk mendapatkan tegangan analog keluaran sensor $\left(V_{R L}\right)$ dapat digunakan persamaan

$V_{R L}=\left(\frac{\text { Sensorvalue }}{1024}\right) \times 5$

Dimana Sensorvalue adalah nilai data digital hasil pembacaan keluaran sensor oleh mikrokontroller melalui ADC internal.

\section{Sensor MQ135}

Kurva karakteristik sensor di perlihatkan pada Gambar 5. Kurva ini diperoleh dari datasheet sensor MQ135. Untuk mendapatkan persamaan sensor, langkah yang dilakukan sama seperti sensor MQ7 sebelumnya. 


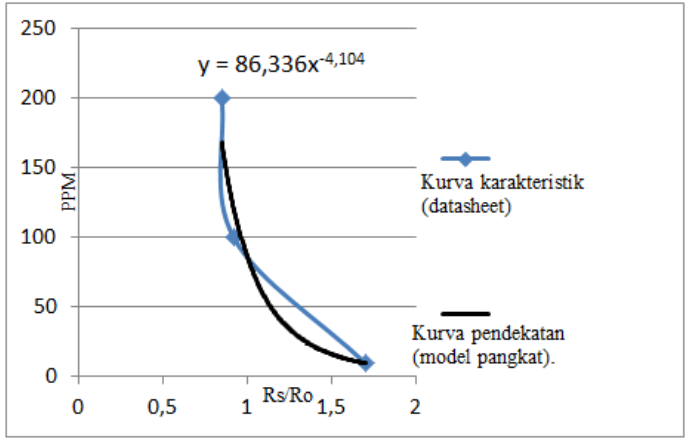

Gambar 5. Kurva karakteristik sensor MQ135

Persamaan kurva pendekatan yang diperoleh tersebut dijadikan sebagai persamaan konversi dari nilai Rs/Ro menjadi ppm, yaitu

$P P M_{N O 2}=86,336 \times\left(R_{S} / R_{o}\right)^{-4,104}$

dimana $P P M_{N O 2}$ adalah konsentrasi gas $\mathrm{NO}_{2}$ dalam satuan $\mathrm{ppm}, R_{s}$ adalah resistansi sensor MQ135 pada saat pengukuran dengan kondisi udara yang berbedabeda, dan $R_{o}$ adalah resistansi sensor MQ135 pada saat kondisi udara bersih $(6000 \Omega)$.

Resistansi sensor saat pengukuran $\left(R_{S}\right)$ diperoleh dari perhitungan,

$R_{s}=\left(\left(V_{c} / V_{R L}\right)-1\right) R_{L}$

dimana $V_{c}$ adalah tegangan rangkaian sensor (5 V), $V_{R L}$ adalah tegangan analog keluaran rangkaian modul sensor, dan $R_{L}$ adalah resistansi keluaran rangkaian modul sensor $(10 \mathrm{~K} \Omega)$.

Karena ADC yang digunakan sama, maka persamaan (3) dapat digunakan untuk menghitung $V_{R L}$ pada sensor MQ135.

\section{Sensor MQ136}

Kurva karakteristik sensor di perlihatkan pada Gambar 6. Kurva ini diperoleh dari datasheet sensor MQ136. Untuk mendapatkan persamaan sensor, langkah yang dilakukan sama seperti sensorsensor sebelumnya.

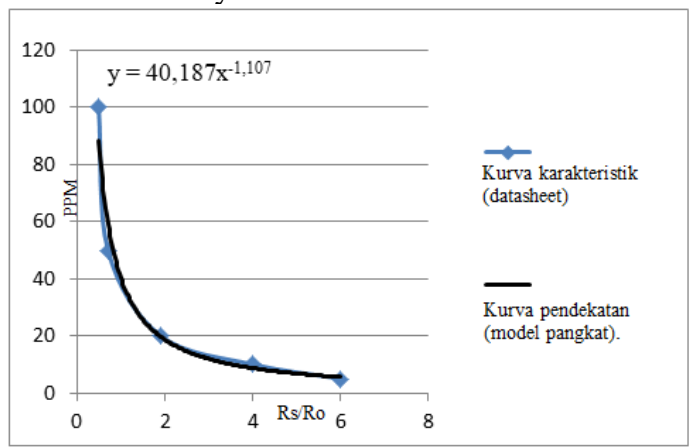

Gambar 6. Kurva karakteristik sensor MQ136

Persamaan kurva pendekatan yang diperoleh tersebut dijadikan sebagai persamaan konversi dari nilai Rs/Ro menjadi ppm, yaitu

$$
P P M_{S O 2}=40,187 \times\left(R_{S} / R_{o}\right)^{-1,107}
$$

dimana $P P M_{\mathrm{SO}_{2}}$ adalah konsentrasi gas $\mathrm{SO}_{2}$ dalam satuan ppm, $R_{s}$ adalah resistansi sensor MQ136 pada saat pengukuran dengan kondisi udara yang berbedabeda, dan $R_{o}$ adalah resistansi sensor MQ136 pada saat kondisi udara bersih (6890 $\Omega$ ).

Model rangkaian sensor MQ136 sama dengan MQ135, sehingga persamaan (5) dapat digunakan untuk mencari $V_{R L}$ pada sensor MQ136. Persamaan (3) juga dapat digunakan kembali karena ADC yang digunakan sama.

\section{Sensor MQ131}

Kurva karakteristik sensor di perlihatkan pada Gambar 7. Kurva ini diperoleh dari datasheet sensor MQ131. Untuk mendapatkan persamaan sensor, langkah yang dilakukan sama seperti sensorsensor sebelumnya.

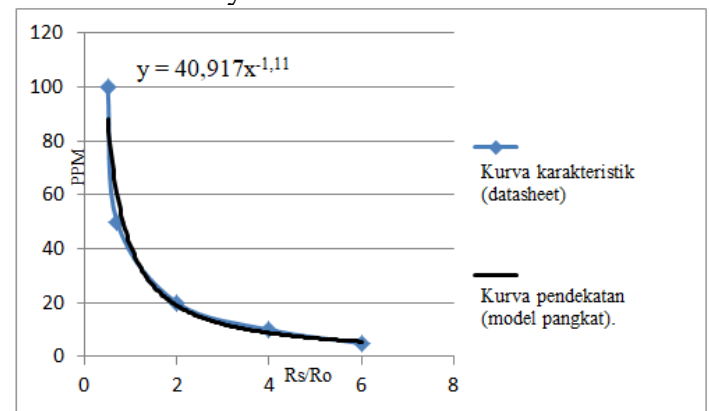

Gambar 7. Kurva karakteristik sensor MQ131

Persamaan kurva pendekatan yang diperoleh tersebut dijadikan sebagai persamaan konversi dari nilai Rs/Ro menjadi ppm, yaitu

$P P M_{O 3}=40,91 \times\left(R_{S} / R_{o}\right)^{-1,11}$

dimana $P P M_{O 3}$ adalah kadar oksidan dalam bentuk ozon (O3) dalam satuan ppm, $R_{s}$ adalah resistansi sensor MQ131 pada saat pengukuran dengan kondisi udara yang berbeda-beda, dan $R_{o}$ adalah resistansi sensor MQ131 pada saat kondisi udara bersih (5000 $\Omega)$.

Model rangkaian sensor MQ131 sama dengan MQ135, sehingga persamaan (5) dapat digunakan untuk mencari $V_{R L}$ pada sensor MQ131. Persamaan (3) juga dapat digunakan kembali karena ADC yang digunakan sama.

\section{Sensor GP2Y1010AU0F}

Kurva karakteristik sensor di perlihatkan pada Gambar 8. Kurva ini diperoleh dari datasheet sensor GP2Y1010AU0F. Pada kurva tersebut terlihat bahwa pada rentang kerapatan debu (Dust density) 0$0.5 \mathrm{mg} / \mathrm{m}^{3}$, kurva berupa garis lurus dengan kemiringan 0.17. Sedangkan diatas Dust density 0.5 $\mathrm{mg} / \mathrm{m}^{3}$ berupa garis mendatar. 


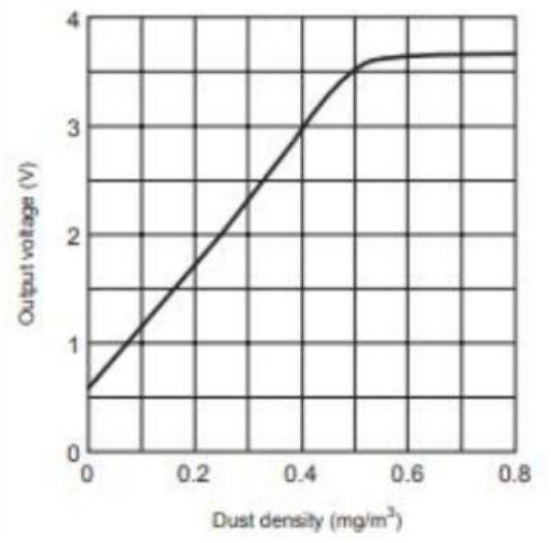

Gambar 8. Kurva karakteristik sensor GP2Y1010AU0F

Oleh karena itu, hasil pengukuran hanya untuk rentang $0-5 \mathrm{mg} / \mathrm{m}^{3}$. PM10 dalam ISPU dinyatakan dalam satuan $\mu \mathrm{m} / \mathrm{m}^{3}$, sehingga hasil perhitungan Dust density perlu dikalikan dengan 1000 untuk mendapatkan nilai partikulat PM10.

Mikrokontroller yang digunakan memiliki ADC internal dengan resolusi 10bit dan tegangan referensi 5V. Dengan demikian, persamaanpersamaan untuk melakukan konversi dari nilai tegangan keluaran modul sensor yang terbaca menjadi partikulat PM10 adalah

$$
\begin{aligned}
& \text { calcVoltage }=\left(\frac{\text { Sensorvalue }}{1024}\right) \times 5 \\
& \text { voltDensity }=\text { calcVoltage }-0,1 \\
& \text { dustDensity }=\text { calcVoltage } \times 0,17 \\
& P M 10=\text { dustDensity } \times 1000
\end{aligned}
$$

\section{Hasil dan Pembahasan}

Hasil realisasi Sensor Node diperlihatkan pada Gambar 9. Terlihat bahwa setiap sensor diletakkan di lokasi yang berdekatan dengan lubang ventilasi kemasan sensor node. Hal ini dilakukan agar hasil pengukuran menggambarkan udara di luar kemasan sensor, bukan kondisi di dalam kemasan.

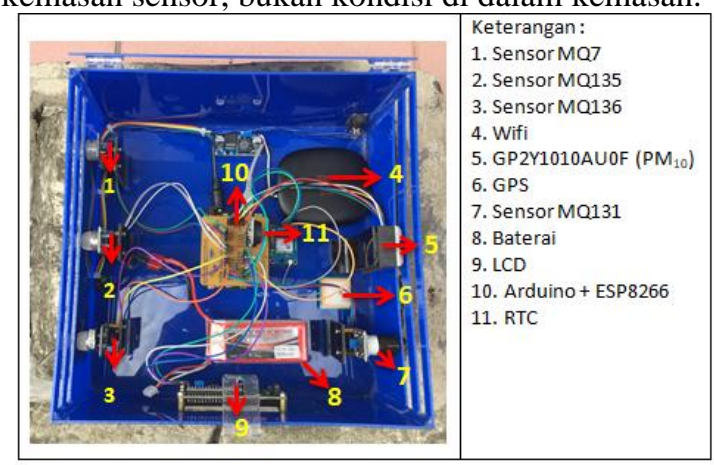

Gambar 9. Realisasi dan tata letak sensor pada kemasan sensor node

Pengujian Sensor MQ7 (CO) dan MQ135 $\left(\mathrm{NO}_{2}\right)$
Pengujian dilakukan dengan meletakkan sensor pada pembuangan asap kendaraan bermotor dengan tahun pembuatan yang berbeda. Sebagaimana diketahui bahwa gas $\mathrm{CO}$ dan $\mathrm{NO}_{2}$ merupakan diantara gas yang dihasilkan dari pembuangan asap kendaraan bermotor.

Pengujian ini bertujuan untuk menguji apakah data pengukuran sensor node menunjukkan peningkatan berdasarkan usia atau masa pakai kendaraan. Kendaraan yang memiliki tahun lebih tua akan menghasilkan gas buang yang lebih banyak mengandung polutan atau memiliki kandungan gas $\mathrm{CO}$ dan $\mathrm{NO}_{2}$ lebih tinggi, sebagaimana dinyatakan oleh (Muziansyah, Sulistyorini, \& Sebayang, 2015). Pengukuran dilakukan selama 27 detik dan dihitung nilai rata-rata konsentrasi gasnya selama rentang waktu pengukuran tersebut. Hasil pengukuran gas buang pada tiga kendaraan yang tahun pembuatannya berbeda dapat dilihat pada Tabel 1 .

Tabel 1. Hasil pengujian sensor MQ7 (CO) dan MQ135 $\left(\mathrm{NO}_{2}\right)$

\begin{tabular}{lccc}
\hline $\begin{array}{c}\text { Sepeda } \\
\text { Motor }\end{array}$ & $\begin{array}{c}\text { Tahun } \\
\text { Pembuatan }\end{array}$ & $\begin{array}{c}\text { Rata-rata gas } \\
\mathrm{CO}(\mathrm{ppm})\end{array}$ & $\begin{array}{c}\text { Rata }- \text { Rata gas } \\
\mathrm{NO}_{2}(\mathrm{ppm})\end{array}$ \\
\hline N MAX & 2019 & 75,22 & 2,79 \\
\hline BEAT & 2016 & 125,70 & 3,38 \\
\hline F1Z & 1999 & 303,372 & 6,47 \\
\hline
\end{tabular}

Hasil dari perbandingan nilai kadar $\mathrm{CO}$ dan $\mathrm{NO}_{2}$ pada sensor MQ7 dan MQ135 menunjukkan bahwa sensor sudah bisa membaca kadar gas dalam satuan ppm secara baik. Hal ini terlihat dengan membandingkan nilai ppm pada 3 jenis motor yang berbeda. Dimana gas buang pada motor F1Z (1999) memiliki kadar gas $\mathrm{CO}$ dan $\mathrm{NO}_{2}$ yang paling tinggi, motor BEAT (2016) pertengahan, dan motor NMAX (2019) paling rendah.

\section{Pengujian Sensor MQ136 (SO2)}

Pengujian ini bertujuan untuk melihat apakah sensor telah dapat mendeteksi adanya gas $\mathrm{SO}_{2}$ dan menunjukkan peningkatan nilai hasil pengukuran. Untuk kemudahan pengujian, gas $\mathrm{SO}_{2}$ yang diukur berasal dari gas elpiji rumah tangga. Gas elpiji ini merupakan gas alam yang disimpan dalam tabung gas dan diberi tambahan unsur sulfur untuk memberikan efek bau sehingga mudah tercium ketika terjadi kebocoran. Pengujian dilakukan dengan dua kondisi. Pertama, sensor diletakkan di udara bebas dan jauh dari katup bukaan tabung elpiji. Kedua, sensor diletakkan di dekat katup bukaan tabung elpiji. Data diambil dalam rentang waktu 27 detik.

Hasil pengukuran rata-rata konsentrasi $\mathrm{SO}_{2}$ pada kondisi pertama adalah 13,89 ppm. Sedangkan pada kondisi kedua sebesar 81,70 ppm. Hasil ini menunjukkan bahwa sensor telah mampu mendeteksi adanya konsentrasi gas $\mathrm{SO}_{2}$ yang lebih tinggi di dekat bukaan katup tabung elpiji. 


\section{Pengujian Sensor GP2Y1010AU0F (PM10)}

Pengujian ini bertujuan untuk melihat perbandingan data yang dihasilkan sensor GP2Y1010AU0F ketika berada pada udara tanpa intervensi dan ketika berada pada udara yang diberi asap pembakaran kertas. Waktu pengambilan data selama 2 menit 3 detik. Hasil pengukuran ditunjukkan pada Gambar 10. Terlihat bahwa terjadi kenaikan partikulat yang terukur ketika pada sensor node diberi perlakukan berupa asap dari pembakaran kertas. Ini menunjukkan bahwa sensor pertikulat PM10 telah bekerja.

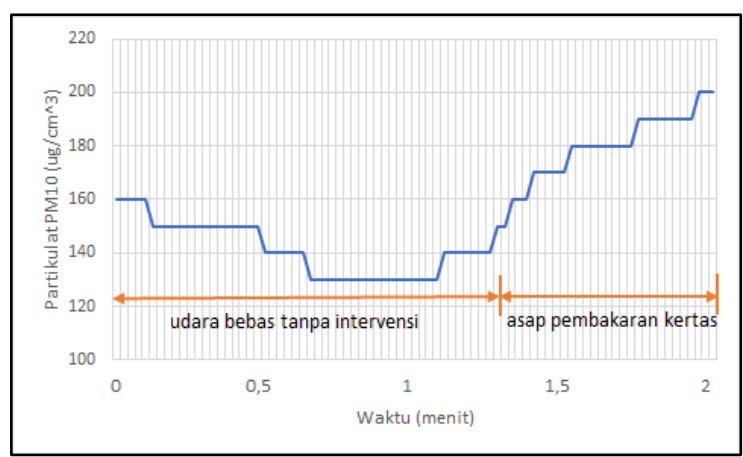

Gambar 10. Hasil pengukuran partikulat PM10 saat kondisi udara bebas dan setelah diberi asap

\section{Pengujian Pengiriman Data ke Server Database}

Teknik pengujian ini mengunakan sensor node yang terkoneksi dengan jaringan wifi, dan melihat data yang terupdate pada server database. Pada pengujian ini, dua buah sensor node diletakkan di dua lokasi berbeda. Sensor Node 1 diletakkan di dekat pintu gerbang kampus Politeknik Caltex Riau, sedangkan Sensor Node 2 diletakkan di SMPN 22, Kota Pekanbaru. Gambaran lokasi kedua sensor node dapat dilihat pada Gambar 10.

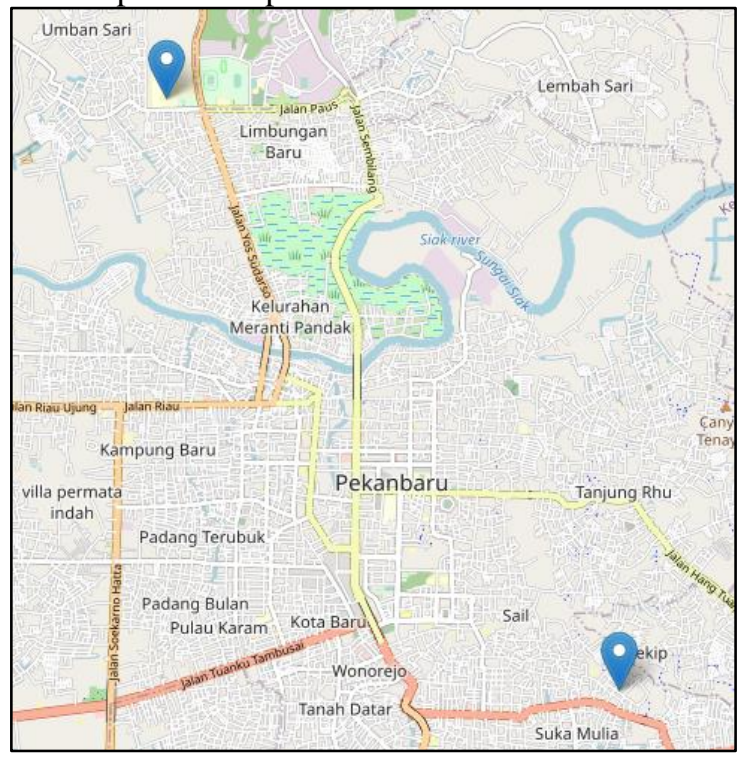

Gambar 11. Peta lokasi Sensor Node 1 dan Sensor Node 2

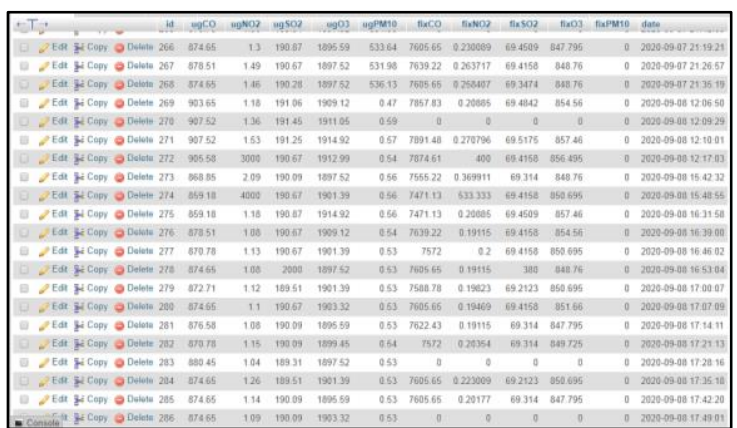

Gambar 12. Data terupdate dari Sensor Node 1

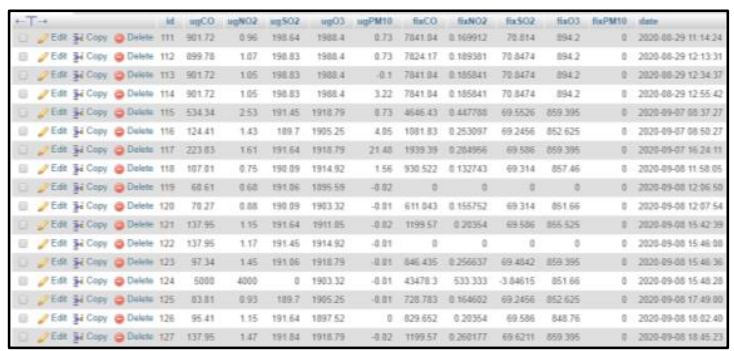

Gambar 13. Data terupdate dari Sensor Node 2

Dari cuplikan tabel data yang terdapat pada server database, seperti ditunjukkan pada Gambar 12 dan 13, terlihat bahwa kedua sensor node ini sudah dapat mengirimkan data ke server database dengan baik sesuai dengan apa yang diingankan. Selama Sensor Node 1 dan Sensor Node 2 aktif, maka data akan terus terupdate setiap 30 menit sekali.

Selain pengujian pengiriman data seperti diuraikan di atas, dalam pengujian ini juga dilakukan pengukuran parameter tingkat keberhasilan pengiriman data. Parameter yang digunakan adalah packet loss dan latency. Pengujian dengan alat bantu network capture, diperoleh hasil rata-rata packet loss $13,6 \%$ dan latency $58 \mathrm{~ms}$. Mengingat bahwa data yang dikirim hanya berupa text dan jeda waktu pengiriman antar data adalah 30 menit, hasil ini sudah bisa dikategorikan cukup untuk keperluan pengiriman data sensor ke server.

\section{Kesimpulan dan Saran}

Hasil pengujian menunjukkan bahwa secara keseluruhan sistem pada sensor node dapat berjalan baik dan data hasil pengukuran berhasil dikirim ke server. Nilai hasil pengukuran parameter udara yang dibaca pada sensor sudah masuk ke dalam rentang batas nilai pengukuran masing-masing parameter. Meskipun nilai yang terbaca pada masing-masing sensor belum melalui pengujian akurasi, tetapi telah menunjukkan hasil pengukuran yang logis. Untuk pengembangan selanjutnya, di perlukan pengujian akurasi dan kalibrasi sehingga diperoleh data sensor yang lebih akurat. 


\section{Ucapan Terima Kasih}

Ucapan terima kasih disampaikan kepada Politeknik Caltex Riau yang telah mendanai penelitian ini melalui program Hibah Penelitian Internal tahun 2020.

\section{Daftar Pustaka}

[1] Aida, N. R. (2019, September 13). Kabut Asap dan Karhutla Riau, Peristiwa Tahunan yang Selalu Berulang. Dipetik April 5, 2020, dari Kompas.com: https://www.kompas.com/tren/read/2019/ 09/13/194927565/kabut-asap-dankarhutla-riau-peristiwa-tahunan-yangselalu-berulang

[2] Arty, I. S. (2005). Peran Udara Dalam Kehidupan Kaitannya Dengan Pandangan Hidup Masyarakat Indonesia. Seminar Nasional Penelitian, Pendidikan \& Penerapan MIPA (hal. K-83 - K-90). Yogyakarta: FMIPA-UNY.

[3] Greenstone, M., \& Fan, Q. (. (2019). Kualitas Udara Indonesia yang Memburuk dan Dampaknya terhadap Harapan Hidup. Chicago: Energy Policy Institute at the University of Chicago (EPIC). Diambil kembali dari https://aqli.epic.uchicago.edu/wpcontent/uploads/2019/03/Indonesia.Indone sian.pdf

[4] Gupta, H., Bhardwaj, D., Agrawal, H., Tikkiwal, V., \& Kumar, A. (2019). An IoT Based Air Pollution Monitoring System for Smart Cities. IEEE International Conference on Sustainable Energy Technologies and Systems (ICSETS) (hal. 173-177). Bhubaneswar, India: IEEE. doi:10.1109/ICSETS.2019.8744949

[5] IQAir. (2020). 2019 World Air Quality Report. Staad, Switzerland: IQAir.

[6] Muziansyah, D., Sulistyorini, R., \& Sebayang, S. (2015). Model Emisi Gas Buangan Kendaraan Bermotor Akibat Aktivitas Transportasi (Studi Kasus: Terminal Pasar Bawah Ramayana Kota Bandar Lampung). Journal Rekayasa Sipil Dan Desain (JRSDD), 3(11), 57-70.

[7] Prabowo, K., \& Muslim, B. (2018). Bahan Ajar Kesehatan Lingkungan: Penyehatan Udara. Jakarta: Pusat Pendidikan Sumber Daya Manusia Kesehatan - Kementerian Kesehatan Republik Indonesia.
[8] Savitri, W. M. (2016). Sistem Monitoring Kandungan Partikulat PM2.5 Untuk Mendeteksi Kualitas Udara. Pekanbaru: Pustaka Politeknik Caltex Riau.

[9] Suwedi, N., Rifa'i, A., \& Sujana, C. (2018). Pengembangan Sistem Monitoring Kualitas Udara Perkotaan. Prosiding Seminar Nasional dan Konsultasi Teknologi Lingkungan (hal. 52-57). Jakarta: Pusat Teknologi LingkunganBPPT.

[10] Syukur, M. (2019, September 20). Lelah, Sudah 22 Tahun Karhutla dan Kabut Asap Menghantui Riau. Dipetik April 5, 2020, dari Liputan6.com: https://www.liputan6.com/regional/read/4 066978/lelah-sudah-22-tahun-karhutladan-kabut-asap-menghantui-riau

[11] Timisela, J. A. (2011). Sistem Monitoring Kualitas Udara Menggunakan Komunikasi Wireless YS-1020. Pekanbaru: Pustaka Politeknik Caltex Riau. 